\author{
László Varga \\ PhD Student (Political Science) of Interdisciplinary Doctoral School \\ e-mail:vargalaci108@gmail.com,ORCID ID: https://orcid.org/0000-0003-0555-331X \\ University of Pécs, Ifjúságútja 6, H-7624 Pécs, Hungary
}

\title{
A GRASSROOTS DEVELOPMENT IN THE LIGHT OF THE DEVELOPMENT THEORIES, A CASE STUDY IN RURAL INDIA: FOOD FOR LIFE VRINDAVAN
}

In this study, the activities of a volunteer based grassroots development in rural India - Food for Life Vrindavan (FFLV) are presented. A thorough examination of how it complies with the dimensions established in the scientific literature about grassroots and social innovations and what the characteristics of its activities are in the light of the latest trends in human development is performed.

The article is organised into six sections: after a short introduction about the subject, the objectives and the layout of the paper, section 2 presents the timeline of the development industry with a particular emphasis on the process of turning from national economy boosting initiatives to the dimensions of human development. In section 3 the key elements in the literatures on the capability approach and grassroots/social innovations are presented. Section 4 introduces the case of FFLV, followed by a detailed analysis in section 5 where FFLV's position with regards to the different perspectives is discussed. In section 6 , the quantitative analysis is conducted. Concluding the paper in the final section, some reflections on the usefulness of the study are mentioned.

Based on the results of the conducted research the following conclusions have been made: 1) In the beginning, Food for Life Vrindavan was an entirely volunteer based grassroots innovation. With a gradual increase in the number of people it served and subsequent expansion in it's fields of services, it has become a social innovation. 2) The characteristics of FFLV's activities fit into the dimensions of human development established by the United Nations based on Amartya Sen's concept of capability approach. 3) The financial resources of FFLV are modest in comparison to the OECD financed development industry, with the former having access to merely a quarter of the latter's "per capita" funds available for the area of activity around Vrindavan.

Keywords: development industry, self-development, community, grassroots social movement, human development, women's education, poverty alleviation.

Ласло Варга. СТИХІЙНИЙ РОЗВИТОК У СВІТЛІ ТЕОРІЙ РОЗВИТКУ, ТЕМАТИЧНЕ ДОСЛДЖЕННЯ У СІЛЬСЬКІЙ ІНДІї: ПРОДОВОЛЬСТВО ДЛЯ жИТТЯ ВРІНДАВАНА

У цьому дослідженні представлена діяльність волонтерського руху на низовому рівні в сільській Індії - Продовольство для життя Вріндавана (FFLV). Проводиться ретельне вивчення того, як він відповідає параметрам, встановленим у науковій літературі, про масові і соціальні інновації, і які особливості його діяльності у світлі останніх тенденцій в розвитку людини.

Стаття складається $з$ шести розділів: після короткого вступу про предмет, завданням і план документа, в розділі 2 представлені тимчасові рамки розвитку галузі з особливим акцентом на процес переходу від ініціатив зі стимулювання національної економіки до вимірювання людського розвитку. У розділі 3 представлені ключові елементи літератури про можливі підходи і масові / соціальні інновації. У розділі 4 представлено приклад FFLV, після чого наведено докладний аналіз у розділі 5, де обговорюється позиція FFLV по відношенню до різних точок зору. У розділі 6 проводиться кількісний аналіз. Висновок статті в останньому розділі, наведено деякі роздуми про корисність дослідження.

За результатами проведеного дослідження були зроблені наступні висновки: 1) Спочатку програма «Продовольство для життя» у Вріндаваны була заснована виключно на добровільних засадах масових інновацій. 3 поступовим збільшенням числа людей, що обслуговуються, і подальшим розширенням сфери послуг це стало соціальною інновацією. 2) Характеристики діяльності FFLV вписуються в аспекти людського розвитку, встановлені ООН на основі концепції підходу на основі можливостей Амартья Сена. 3) Фінансові ресурси FFLV є скромними у порівнянні з фінансованою ОЕСР галуззю промисловості, причому організація має доступ лише до чверті коштів «на душу населення» в районі діяльності навколо Вріндавана.

Ключові слова: індустрія розвитку, саморозвиток, суспільство, масовий громадський рух, людський розвиток, освіта жінок, боротьба з бідністю.

Ласло Варга. СТИХИЙНОЕ РАЗВИТИЕ В СВЕТЕ ТЕОРИЙ РАЗВИТИЯ, ТЕМАТИЧЕСКОЕ ИССЛЕДОВАНИЕ В СЕЛЬСКОЙ ИНДИИ: ПРОДОВОЛЬСТВИЕ ДЛЯ ЖИЗНИ ВРИНДАВАНА

В этом исследовании представлена деятельность волонтерского развития на низовом уровне в сельской Индии Продовольствие для жизни Вриндавана (FFLV). Проводится тщательное изучение того, как оно соответствует параметрам, установленным в научной литературе, о массовых и социальных инновациях, и каковы особенности его деятельности в свете последних тенденций в развитии человека.

Статья состоит из шести разделов: после краткого введения о предмете, задачам и план документа, в разделе 2 представлены временные рамки развития отрасли с особым акцентом на процесс перехода от инициатив по стимулированию национальной экономики к измерения человеческого развития. В разделе 3 представлены ключевые элементы литературы о возможных подходах и массовых / социальных инновациях. В разделе 4 представлен пример FFLV, после чего следует подробный анализ в разделе 5, где обсуждается позиция FFLV в отношении различных точек зрения. В разделе 6 проводится количественный анализ. Заключение статьи в последнем разделе, приведены некоторые размышления о полезности исследования. 
По результатам проведенного исследования были сделаны следующие выводы: 1) Вначале программа «Продовольствие для жизни» во Вриндаване была основана исключительно на добровольных началах массовых инноваций. С постепенным увеличением числа обслуживающихся людей и последующим расширением сферы услуг это стало социальной инновацией. 2) Характеристики деятельности FFLV вписываются в аспекты человеческого развития, установленные ООН на основе концепции подхода на основе возможностей Амартья Сена. 3) Финансовые ресурсы FFLV являются скромными по сравнению с финансируемой ОЭСР отраслью промышленности, причем организация имеет доступ лишь к четверти средств «на душу населения» в районе деятельности вокруг Вриндавана.

Ключевые слова: индустрия развития, саморазвитие, общество, массовое общественное движение, человеческое развитие, образование женщин, борьба с бедностью.

1. Introduction. The economy of Europe after World War II needed a significant boost to recover and based on the successful delivery of the Marshal plan, in the decades to follow many theories were born for regional development. In the early stages, development was sought through high economic growth. It had been hoped that these endeavours would have the same beneficial effects no matter where they were used, but over the course of the last 60-70 years it has become very clear, that exporting an idea without consideration of the cultural differences and the local circumstances will have different outcomes. Learning from these bitter experiences, currently development is seen in terms of extending human capabilities of life. Sen's capability approach (CA) [1] has certainly been a breakthrough and saw the ideas and efforts of the scientific community penetrate the development industry. Leading up to the birth of the CA, social scientists had analyzed what had happened [2] but the CA was the required paradigm shift for the prevalent thought on the meaning of development to be reorganized. Although it has remained a top-down planning and financially executing system, the United Nations (UN) has created the Dimensions for Human Development (DHD) [3], an evaluating and guiding structure of attributes that are achievable goals too.

Parallel to this, the number of analytical theories increased significantly and numerous studies have been carried out in order to describe the opposing bottom-up development. Publications concerning Grassroots Associations (GA) [4], Grassroots Innovations (GI) [5] and Social Innovations (SI) [6] have become substantial. A literature overview conducted by Hossein states that the number of articles in English about GI available online is well over a 100 [7]. Alkire goes even further by showing that the different lists regarding what are "good" dimensions for human development has reasonably expanded [8]. These theoretical approaches have a sincere will to describe the experienced reality, but in general they focus on momentary snapshots without providing a thorough examination of the history of the given cases.

This study approaches the analysis using timelines, presenting more than a cross-sectional picture at a given time. The first timeline starts with the Marshall plan and continues on till the DHD. The primary milestones pertaining to the transformation of the strictly top-down "Big Push" approach into a bottom-up supporting discipline are highlighted. The second timeline shows the evolution of a local, volunteer initiated activity in rural Northen-India - Food For Life Vrindavan (FFLV) within the GI-SI framework, while presenting its operation.

The questions I intend to answer are:

A. Where does FFLV fit in? In other words, are there any differences within the two analytical systems i.e. DHD and GI-SI when it comes to describing an activity?

B. Is it intelligible to perform a quantitative comparison of the big scale development industry and a local activity based on their "per capita" available monetary resources?

For timeline 1, a descriptive method relying on secondary sources is used. Timeline 2 is a combination of literature analysis and the systematic organization of information gathered during more than 20 years of personal interactions with FFLV's activities, manifested in several visits to its locality, active participation in certain functions, interviews with activists and locals and access to some original documents.

The paper is organised as follows: section 2 presents the timeline of the development industry focusing more on the process of turning from national economy boosting initiatives to the DHD. In section 3 the key elements in the literatures on CA, GI and SI are presented. Section 4 introduces the case of FFLV, then in section 5 (analysis) the perspectives into which FFLV can fit into are discussed. In section 6, quantitative data is presented and the comparative analysis is conducted. Concluding the paper, in the final section some reflections on the usefulness of the study are mentioned.

2. From the Critical Margin till Human Development. The successful Western European reconstruction program after World War II. gave birth to an international large-scale philanthropic mechanism that has come to be known as the development industry. State governments, international organizations, international charities and social movements have been working together with the aim of fighting against the causes of poverty and inequality. How these institutions have been doing this is widely debated and the development industry has been reinventing its strategy almost once in every ten years since its beginnings in the 1950s, figure 1 . From supporting states to supporting markets, its focus has shifted in line with global politics. The development thinkers have proposed many theories and models, which view development from different perspectives recommending different measures to achieve the desired goal.

The original theories and models of development took birth in the West and were meant for Western societies' cultures and conditions. Later these development models, though western-oriented, were recommended for the countries of the Third World. It was hoped that they would have the same beneficial effects, but it turn out differently. A World Bank document for example reveals that the implementation of the Structural Adjustment Programs (SAPs) in the ' 80 s caused “...several social costs, including increased unemployment; deterioration 
in real per capita incomes; increasingly unequal distribution of incomes; and reduced expenditures on infrastructure, public utilities, health, education, and other services" [9]. It started to become clear that traditional societies with a culture rather different to the EuroAtlantic ways of life might slip into a modern form of poverty without ever even tasting the promised advantages of modernization. The problems of poverty are rather complicated. People living in poverty have no access to the resources, not even to the information why to access them. Billions of dollars are being spent every year in the Third World but, with few exceptions, poverty is increasing [10], more people are hungry and development projects are destroying the environment, the basis of all life [11]. Table 1 shows the total donations registered by Organization for Economic Cooperation and Development (OECD) from 1960-2016.

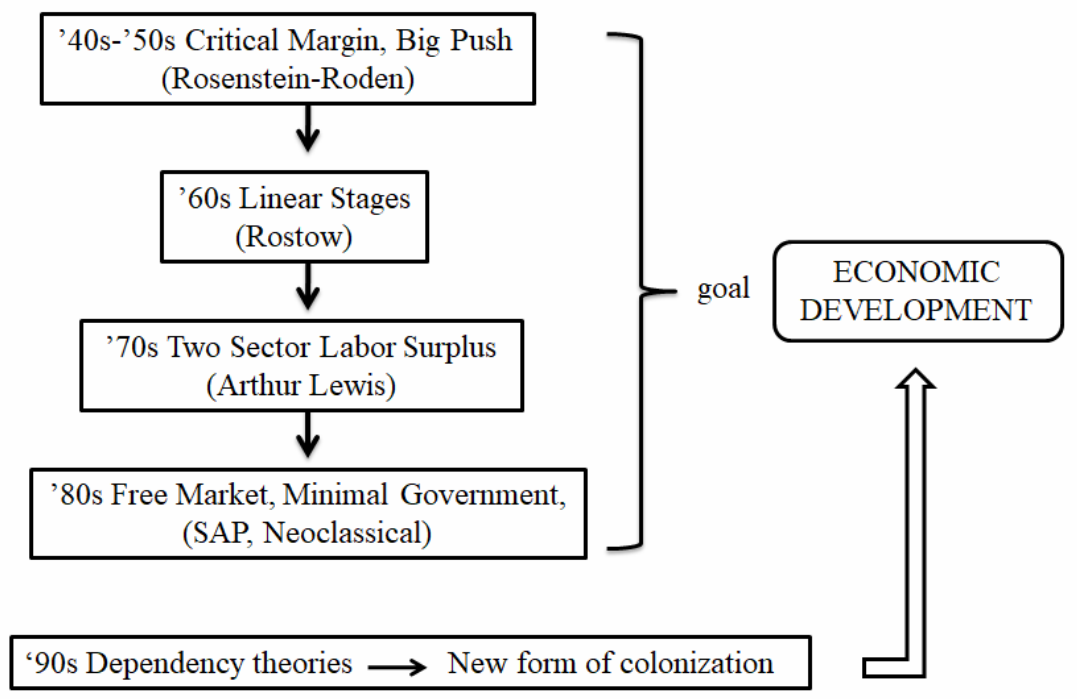

\section{PARADIGM SHIFT IS NEEDED}

Fig. 1. The evolution of the development theories from 1940-1990

Source: own work

Total donations for OECD 1960-2016

\begin{tabular}{|c|c|c|}
\hline Period & USD million & CUM \\
\hline $1960-1970$ & 67.754 & 67.764 \\
\hline $1971-1980$ & 202.239 & 270.003 \\
\hline $1981-1990$ & 425.529 & 695.532 \\
\hline $1991-2000$ & 623.935 & 1.319 .467 \\
\hline $2001-2010$ & 1.094 .981 & 2.414 .448 \\
\hline $2011-2016$ & 996.857 & 3.414 .305 \\
\hline
\end{tabular}

Source: own work, using data from statd.oecd.org [12]

The group of theories which grew out from the critics of the above mentioned modernization theories and their mostly unsuccessful implementations are the dependency theories - the liberal reformers (Prebisch), the Marxists (Andre Gunder Frank), the world systems theorists (Wallerstein) -, and the concept of discourse. These critics agree on certain basic points. They say that the development industry is nothing but a masked way of exercising power over the underdeveloped world, it is the reallocation of the colonial conditions and the projects are widening the gap, increasing the inequality, both on macro and micro levels between the North and the South. According to Ferraro, “...dependency theory attempts to explain the present underdeveloped state of many nations in the world by examining the patterns of interactions among nations and by arguing that inequality among nations is an intrinsic part of those interactions" [13].

The thinkers of discourse analysis, like Michel Foucault express a similar approach in describing the nature of the discourse. He puts the activity of sharing in the focus of the discourse around which power, knowledge and meaning are interrelating. In order to understand the substance of the sharing, discourse analysts look for “... 
the array of relationships connected to contemporary and historical issues..." [14]. It has often been experienced during the execution of a particular development project that new practices, social relations, power and interest poles had come into existence, out of which none were part of the original plan. Such results of the events confirm both theories, in the sense that the patterns of interactions and the nature and substance of the discourse between the parties shape the outcomes of the projects. Development is clearly a contentious concept, but what has become clear is that a troubling divide exists between what Western developers think development entails and how the people affected understand the ensuing processes. "These hegemonic considerations are shown to have a profound effect on the culture of aid and the interface between development personnel and those whom development is supposed to benefit." [15].

Given the above constraints, it is not surprising that a crisis in development has occurred. Due to further critics and the ample information on the questionable successes of the development projects over the last $5 \mathrm{dec}-$ ades, a new way of approach to development started to gain its ground towards the end of the 20th century amongst the development thinkers. There seemed to be an agreement that without the active involvement of the community members within the geographical area to be developed right from the planning stages of the devel- opment, the desired results of the developers will not be realized.These new thoughts initiated a reform within the industry and turned the focus from project delivery to human development. The United Nations Development Program (UNDP) has defined Human Development “...as the process of enlarging people's choices, which choices allowing them to lead a long and healthy life, to be educated, to enjoy a decent standard of living, ... as well as political freedom, other guaranteed human rights and various ingredients of self-respect" [16]. This is a paradigm shift from the orthodox thinking about development, bringing a new light into the field, where the measurement of development - the Human Development Index (HDI) [17] - is based on the human capabilities and well being as opposed to the old school's national economic growth supremacy [18]. Mahbub ul Haq, who played a leading role in the shaping of this new way of approach to development built his work on Amartya Sen's theory of capabilities which is emphasizing, that "...the alleviation of poverty, illiteracy, poor health, violent conflict and political injustice required development policies to be reoriented towards the extension of human choices" [18]. Using the substances of these theoretical words UNDP has clearly defined the dimensions of the human development, figure 2.

\begin{tabular}{|c|c|c|}
\hline \multirow{7}{*}{$\begin{array}{c}\text { Dimensions } \\
\text { of Human Development }\end{array}$} & \multirow{3}{*}{ Directly enhancing human abilities } & Long and healthy life \\
\hline & & Knowledge \\
\hline & & Decent standard of living \\
\hline & \multirow{4}{*}{$\begin{array}{l}\text { Creating conditions } \\
\text { for human development }\end{array}$} & $\begin{array}{c}\text { Paticiption in political } \\
\text { and community life }\end{array}$ \\
\hline & & Environmental sustainability \\
\hline & & Human security and rights \\
\hline & & Gender equality \\
\hline
\end{tabular}

Fig. 2. Dimensions of Human Development Source: [3]

So after all, what is a successful development project? A successful development project should be one that brings a sustainable change in the life of the people whom the project has been crafted for without making irreversible damage in the community's social system and the environment. When people can taste right from the beginning direct benefits from their participation, the project has more chances to get off the ground. As time proved most top-down development projects formulated by bureaucracies fail because they lack this simple but crucial element. Grassroots development activities in general however, have the potential to satisfy this need missing from the large scale - big money operations.

3. Bottom-up processes. Sen describes his view as "The capability approach to a person's advantage is concerned withevaluating it in terms of his or her actual ability to achieve various valuable functionings as a part of living" [1]. The scientific community accepts this idea as the one that ended a long journey into finding a life supporting approach to development. From the Basic Needs $[19,20,21]$ through CA they join with many be- fore $[22,23,24]$ to re-interpret how economic growth can be achieved together with sustainability, while being sensitive to the diversity of the developing regions both culturally and politically [8]. Critics of CA have been actively expressing that Sen has refrained from developing a list of basic capabilities, and a procedure for identifying which categories, and which capabilities within categories, should have priority $[25,26]$. Martha Nussbaum proposed for legislative purposes a list of $10 \mathrm{hu}-$ man capabilities to reach constitutional guaranties for CA [27]. Alkire has gathered the majority of "lists" constructed by prominent scientists like Doyal and Gough, Maureen Ramsay, Shalom Schwartz, Deppa Narayan, Manfred Max-Neef and more, in an attempt to synthetize them by establishing a four point attributum criteria about dimentions [8]:

- ,The dimensions must be valuable.

- The dimensions must combine scope with specificity.

- The dimensions must be critical and complete.

- The dimensions do not pertain to one view of 
the good life."

Case studies however need tangible indicators (attributes and variables) for assessment and comparability. Furthermore, as CA answers the question of ,what?" only, there is a need for tools to answer the „how?”. This issue is dealt with in the Grassroots Organizations (GO), Grassroots Innovations (GI) and Social Innovations (SI) literature. Smith gives his definiton on GO as ,...locally based and wholly volunteer nonprofits..." [4], meaning that a GO has no paid staff. On the definition of the word volunteer there is no clear concensus, but certain features are common: not claiming remuneration, benefiting other/s [28]. Another definition on grassroots, which is used by the European Commission states that "A grassroots organization is a self-organized group of individuals pursuing common interests through a volunteer-based, non-profit organization. Grassroots organizations usually have a low degree of formality but a broader purpose than issue-based self-help groups, communitybased organizations or neighborhood associations." [29]. The speciality of GOs is that they make the needed resources available for locals for sustainable development [30]. GIs emphasize social, cultural and ethical values [31] and stem from the knowledge, experience and skills embedded in communities and individuals for solving local problems [32]. Social Innovation seems to be the next level of GI as it addresses social problems and which, in the first hearing already suggests a wider sphere. And indeed the definitions use words and terms such as "novel solution to a social problem", values created benefit the "society as whole rather than private individuals" [33]. Mughal et al. paraphrase even further by saying that the goal of SIs manifest in ,meeting social needs...through organizations" with social purposes [34].
A clear picture can be drawn from these definitions. $\mathrm{CA}$ gives the quality-content to bottom-up processes whereas GI and SI describe their mechanism. In this context, GI refers to a minor operation at the local level addressing small community processes, and SI represents larger activity reflecting on social-level issues, which of course may consist of several GI activities. The question is, what should we start the investigation with, the quality observations or the mechanisms? Since quality is an attribute of the activity, the functioning must be examined first and once that is known its quality can be described. The dimensions selected by a number of authors to characterize the GI-SI concept are the agents, purposes, drivers and processes [35, 36]:

- Agents are those who participate in the operations in a particular role.

- Purposes answer what the GI-SI is for and at the same time describe the outcomes of the activity.

- Drivers refer to the elements that motivate the innovation.

- Processes deal with the question of how the innovation takes place.

4. Food For Life Vrindavan. The city and the rural area around Vrindavan, which is known amongst the religious people as the land of Radha Rani, have more than 5.000 temples. Some of them are said to be 5.500 years old [37]. In the line of Vaisnava faith the temples serve as gathering places for the devotees to remember the pastimes of Radha and Krishna [38]. Vrindavan is a small town on Indian scale, which qualified as Nagar Palika Parishad [39] in the district of Mathura, in the state of Uttar Pradesh, North India, figure 3. Census India 2011 provides the following data about Vrindavan, table 2.

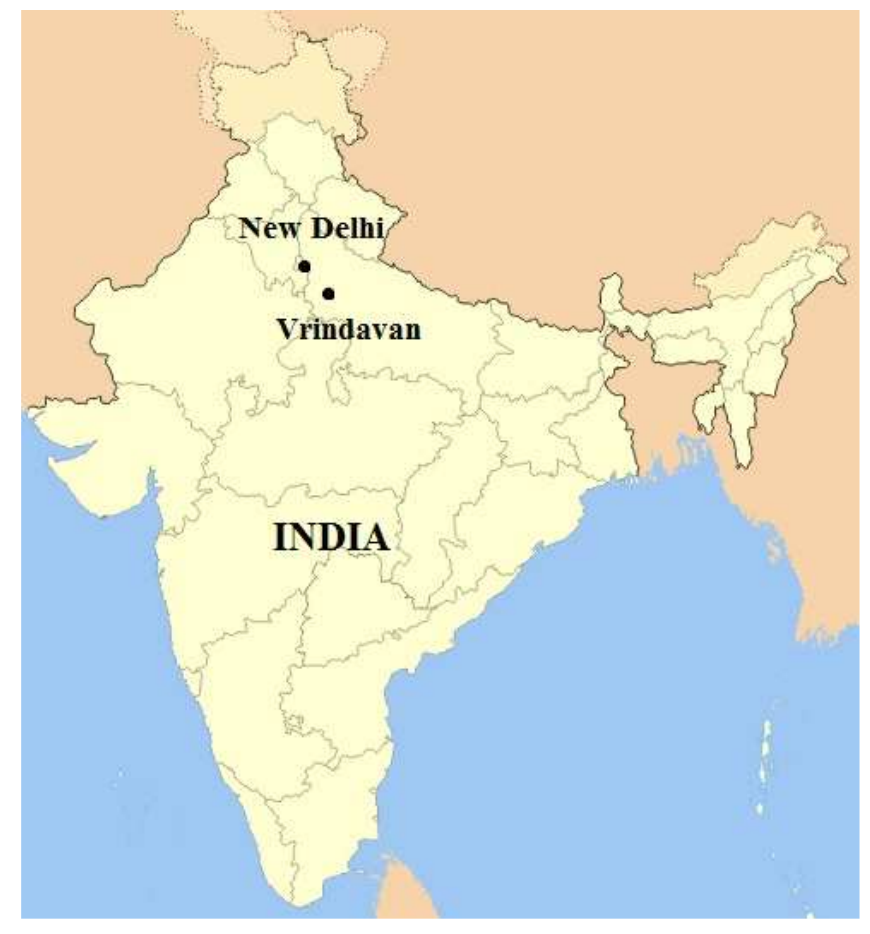

Fig. 3. Vrindavan's location in India

Source: open street maps contributors 
Census India 2011 data about Vrindavan

\begin{tabular}{|l|c|}
\hline Total population & 63.005 \\
\hline Male population & 34.769 \\
\hline Female population & 28.236 \\
\hline Number of children with age 0-6 & $7.818(12,41 \%$ of total) \\
\hline Female sex ratio & 812 (Uttar Pradesh 912) \\
\hline Female child sex ratio & 884 (Uttar Pradesh 902) \\
\hline Literacy & $77,77 \%$ (Uttar Pradesh 67,68\%) \\
\hline Male literacy & $83,74 \%$ \\
\hline Female literacy & $70,32 \%$ \\
\hline
\end{tabular}

Source: own work, using data from Census India 2011 [40]

Around Vrindavan there are many small villages, where the inhabitants' main occupation and source of income is based on agriculture. It has been an old custom in the area to serve pilgrims daily cooked food that was offered to God beforehand [41]. In 1990 a few missionaries connected to one of the temples, the KrishnaBalaram Mandir [42] started their food distribution program. In the years to follow, a widespread, volunteer based, self-financed social development activity grew out:

1993 The daily feeding of Vrindavan's widows starts. In the same year, the daily serving of full meals to about 100 elderly sadhus (saintly mendicants) begins.

1995 Kitchri (rice, bean and vegetable stew) distribution at the temple starts. A daily midday meal distribution at six village schools begins. As news spread around, teachers from other villages started calling the organizers and the daily cooked meal distribution program was extended to fifty-three village schools. This was a turning point for FFLV. By visiting villages the organizers discover the many needs of the villagers. Village elders approached FFLV for help with drinking water, medical assistance, education and other problems arising from poverty.

1997 The first mobile medical team is set up, which goes from village to village giving free advice and medicine.

1998 The first water system in the village of Javat Gaon is built, bringing drinking water to more than 10.000 inhabitants.

1999 The first Social Development Program is organized in seven villages. This consists of adult education, self-help groups and vocational trainings. The same year also sees the start of the tree-planting and environmental cleaning program. FFLV registers with the Indian Government as a NonGovernmental Organization (NGO).

2001 Seeing the number of poor children begging in the streets, an evening educational class program is launched for them, as they did not attend school. The children are taught to read and write. Initially the classes were held at a small public square, later in a tiny rented room within the temple complex. Soon the number of children increased to more than 80 , this gave the idea and the incentive to establish a proper school.

2002 Members of the community and other individuals who visited Vrindavan on pilgrimage give donations to the school project. The school was named Sandipani Muni School (Sandipani Muni was the childhood teacher of Lord Krishna 5.000 years ago). Within a short time the number of children attending the school reaches the limits of the new building.

2003 The collection of donation continues and in October the new Sandipani Muni School is inaugurated, with 200 children attending. The government administration from the district headquarters presents Sandipani Muni School with the prestigious "Model School Award", selecting it above 1.250 other schools.

2004 In October the foundation stone for the Sandipani Muni Secondary School is laid. The funding for the land comes from local and international donors. FFLV was presented the "Human Rights Promotion Award" from the Central Government of India.

2006 Grand Opening of Sandipani Muni Secondary School takes place. Two new projects start in May on World Environment Day, Vishwas and Trees for Life. The Vishwas program helps to beautify Vrindavan by daily cleaning of the roads, alleys, and drains. The goal of Trees for Life is very similar, beautify Vrindavan. The program plants trees and also educates children about their importance. In December, FFLV is presented the "Human Rights Protection Award."

2007 In just the past 4 years the number of children that were enrolled at the Sandipani Muni Schools had more than quadrupled to 830 .

The step-by-step extension of the activities continues even today and FFLV runs many family welfare and educational programs regarding prenatal care, micro finance, primary health care, adult education, HIV, nutrition, basic hygiene, social care and general counseling [43]. Organizers found that amongst the several problems and hardships caused by poverty the most serious one is the condition of the girls in poverty stricken families. Althought India is going through tremendous social and economical progress, it is important to note two fac- 
tors that can appear as hurdles in this development. It is found by empirical research that the socio-economic transformation is much slower in agrarian society than in the urban areas [44], and when development takes place it is creating polarization within the society which deepens the proverty [45]. These two factors combined together might have diverse influence on the social customes, out of which the fact that female children in gen- eral are considered a burden and many Indian families regard them as heavy liabilities [46] is certainly one. The practice of aborting female foetuses is widespread, and the United Nations Children's Fund estimated "...that up to 50 million girls and women are ,missing" from India's population because of termination of the female foetus or high mortality of the girl children due to lack of proper care" [47].

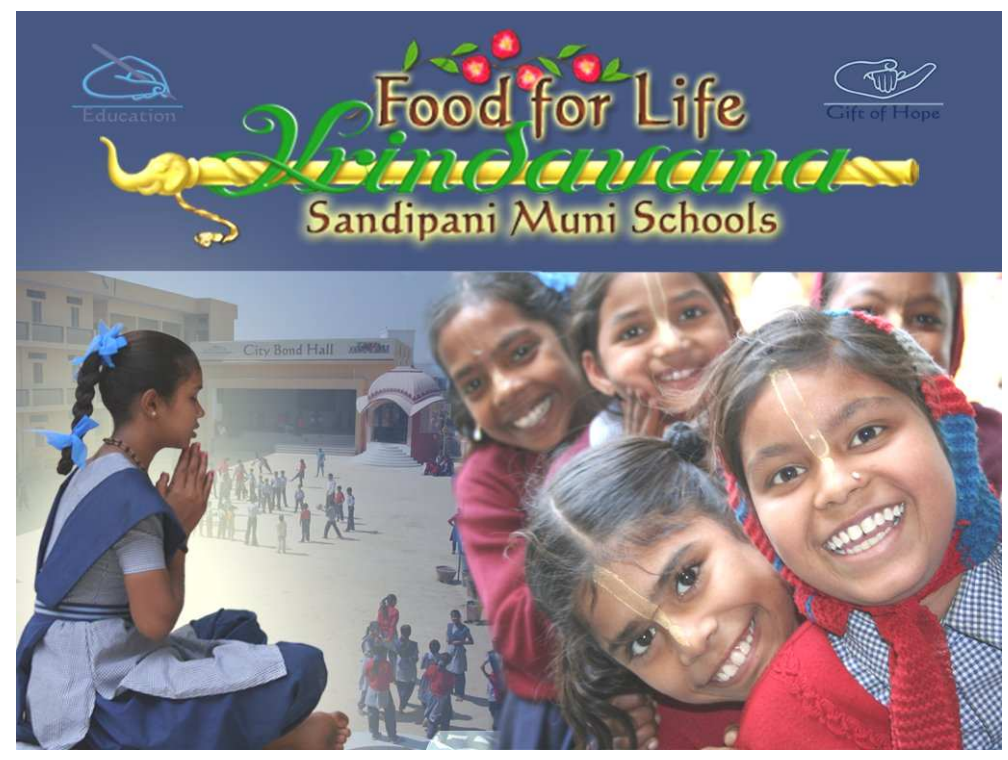

Fig. 4. Sandipani Muni Schools for girls

Source: http://www.fflvrindavan.org/gallery/main.php?g2_itemId $=14400$, retrieved 30.12.2017

The main reason for this is that while sons are expected to stay with their parents and contribute to the family's income after marriage, daughters usually marry and leave home, and their parents have to pay for wedding expenses and provide a dowry to the groom's family. This cultural aspect brings about another questionable practice - girls are given out for marriage at an early age. "One of the major reasons for child marriage is that the younger the girl, the lesser the dowry. The dowry for a twelve-year-old girl is about \$50, whereas for a girl of eighteen, it is \$500” [48]. Even at the local level, FFLV has neither the power nor the capacity to tackle such complex social issues but with wellorganized determination the community can help itself by educating as many girls and women as possible, giving them and their future children the best possible chance in life - to raise the status of women and to break the cycle of poverty. Opening and maintaining schools for girls and holding regular vocational training for women, as well as creating employment opportunities for them are the most effective ways of helping. Currently FFLV trains village-women in fields like embroidery and stitching and then employs them to stitch uniforms for the 1300+ schoolgirls of the Sandipani Muni Schools every year, and also employs them at an embroidery centre. This helps them to support themselves and their families. Employment opportunities are also provided in other fields like work in a paper-recycling factory, organic farming, cleaning staff, drivers, guards, etc. helping the underprivileged to overcome their line of poverty. This employment is a kind of educational proc- ess as well providing a functional example about how the potential rural workforce can be activated [49]. FFLV organizes timely awareness drives, plays, and dances on social issues like child marriage, women abuse etc. to bring social awareness. FFLV “...is educating the girls in fields like karate, martial arts, yoga, classical dances, embroidery, drawing and painting, singing and many others, thus creating potential job opportunities for them in the future" [50]. FFLV has launched a program called "Save Our Girls" to establish a fund that might help as an incentive to the parents to leave the girls in school till they reach maturity and thus save them from childhood marriages [51].

An open national and international sponsorship program has been set up where a person can pledge 35 USD per month to sponsor a girl's education. Out of this 60 USD a year is placed in a special bank account. When the girl reaches the age of 18 and has completed her studies, that money will be given to her. If the girl is taken from school prematurely, the money will stay in the bank account and will be used to help other girls who finish their studies and reach the legal marriageable age [51]. A similar scheme - based only on age not schooling - has also been introduced on state level in the state of Haryana -apni beti apna dhan (our daughter is our wealth) - to avoid childhood marriage [52].

According to the yearly financial statements, FFLV's main source of income is from general donations. Figure 6 shows the donations received between 1997-2011. 


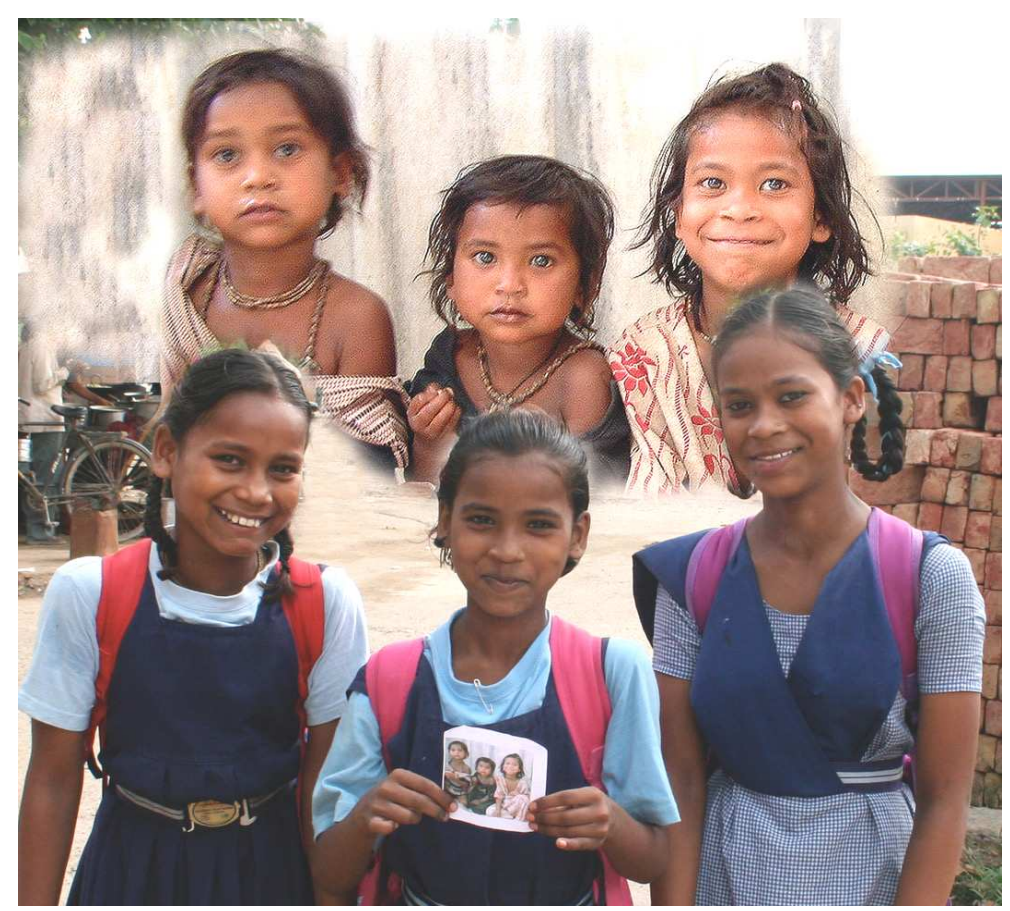

Fig. 5. Save Our Girls program

Source: http://fflvrindavan.com/en_sand/girl-power/her-plight/, retrieved 30.12.2017

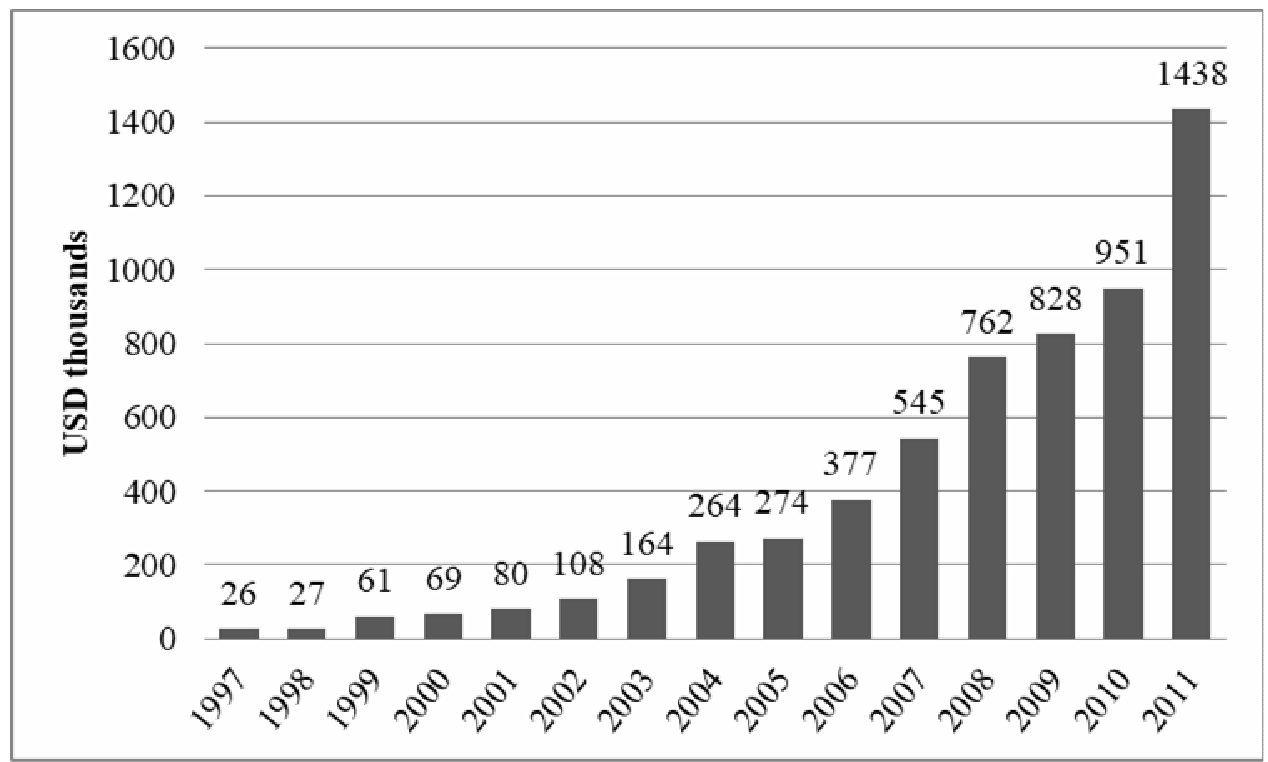

Fig. 6. Donations received by FFLV

Source: own work using data from http://fflvrindavan.com/en_sand/about-us/finances/, retrieved 30.12.2017

This income is contributing to the GDP of India that still needs to arrive to a threshold to attract more foreign investment [53]. There are many volunteers offering free services for FFLV in theVrindavan area and in its offices in other countries [54], so the administrative expenses can be kept below $10 \%$ [55].

5. Comparative analysis. In this section two analyses are conducted. The first deals with how FFLV meets the GI-SI dimensions established in section 3 and examines its characteristics within the CA framework. The second is a quantitative comparison between the incomes of FFLV and the amount of money the top-down organized operations of the development industry receive.

A). From the case study of FFLV a continuous expansion of the activities can be observed. At the starting point the actors' participation was volunteer-based, the operation was minor in size, addressing a local need and satisfying a custom; performing a religious duty. These attributes qualify the activity at this stage for GI. As the operation extended into the social sphere, not only volunteer activists took part in the operation but paid staff 
as well. The scope of the activity has also widened from feeding the mendicants to feeding a large number of children, running several family welfare and educational programs including prenatal care, micro-finance, primary healthcare, adult education, HIV, nutrition, basic hygiene, social care and general counseling; operating schools, organizing vocational training for women, creating employment opportunities for many locals in the schools, the kitchens, on the cultivation lands and sewing workshops. This extended spectrum and volume of activity qualifies FFLV for SI. As for the contents of the dimensions:

i. The agents of the operations are individuals of the civil arena. Initially all participants were volunteer, non-paid personnel and as the activity expanded paid staff became necessary. It is important to observe that although they are paid, their approach to the activity, to the ethos of the operation is the same as for the non-paid volunteers. Neither are agents from the for-profit private sector involved, nor are public bodies.

ii. Regarding the purposes, the GI-SI literature states that, grassroots-social innovations are oriented to promoting solutions to social needs and problems. In the case of FFLV this criteria is met extensively. The alleviation of proverty is a rather complex issue and FFLV with its extended operation touches all the branches of this complexity. However, it has one more purpose, the content of which lies within the religious teachings prevailing in this particular locality. It is thought, that by performing activities the given religious discipline defines as pious - helping others to get relief from poverty and all the sufferings associated with it - the performers absolve themselves of the reactions to past deeds defined as sinful and at the same time receive beneficial credits on the spiritual platform, which can be paraphrased as blessings or heartful well-wishes from the one receiving the service. At this point the two dimensions - purposes and drivers - meet.

iii. Drivers are the motivations that fuel the activity. In this case the drivers of FFLV have extended in the same way as the purposes, but right from the begining they have had a dual orientation. At the early GI stage the outward orientation was to be in accordance with the religious duties of feeding the mendicants. The inward orientation of the actors has been the same ever-since, to perform pious deeds in order to get rid of their sinful reactions from previous acts. As the organization grew and the profile extended into SI this dual orientation remained - outward and inward - but in the outward part a new driver was added, the alleviation of poverty, which has become far more weighty than the initial outward driver, and certainly much more layered.

iv. The fourth dimension - the processes - is rather complex. The necessary tasks are carried out by both unremunerated volunteers and paid staff. To finance the activities, donations are collected worldwide. The majority of the donations, both in number and in sum come from private individuals and a minor part from other NGOs, mainly foundations with poverty alleviation objectives. In order to facilitate the collection of donations on a worldwide scale, regional offices were established in Europe, the US, South-America and Australia. In the- se offices volunteers and paid staff work together to keep in touch with donors, organise events for them and to get new people involved. Through this channel many professionals like teachers, nurses, doctors, handimen, students, administrative workers are informed of FFLV's operations and join its activities in Vrindavan as volunteers for short, 1-3 month periods, and in some cases for lengthier ones.

Now that the dimensional content of FFLV's activities have been established the discussion regarding the characteristics of the results these activities are creating can be commenced. For this enquiry Sen's CA concept is used in the form manifested as the dimensions of human development used by the United Nations. Here the dimensions are divided into two main groups: those that are directly enhancing human abilities: long and healthy life, knowledge, decent standard of living; and those that are creating conditions for human development: participation in political and community life, environmental sustainability, human security and rights, gender equality. The methodology for this enquiry is simple: for the given dimension all the elements relating to it from the case study of FFLV are included. This might seem a repetions of what have already been said but it is important to see them in this context in order to draw the picture about the characteristics of FFLV's results in the light of the CA.

1. Long and healthy life. Genetics and fate have a share in this, but outside of their circle of influence free will has its part as well. FFLV runs many family welfare and educational programs regarding prenatal care, micro finance, primary health care, adult education, HIV, nutrition, basic hygiene, social care and general counseling in order to enlarge the spectrum of free will for the people of Vrindavan.

2. Knowledge. Giving knowledge means empowerment. FFLV's core activity is about empowerment in its full meaning: positioning, enabling, delegation. By operating the schools, girls are positioned in the place where they supposed to be at this age, and by which child-marriage is prevented. Serving nutritious, healthy meals for thousands every day, children and adults are enabled to live a fuller life. Delegation is the most complex of all, since it might take years in the making. There are many young adult women, who from their early childhood have been under the caring wings of FFLV, and now as adults are exemplary figures of the local community as teachers, skilled workers and caring mothers.

3. Decent standard of living. FFLV conducts vocational training for women. With the skills learned, single mothers can enter the local workforce and earn a livelihood, married ones can make a contribution to the family income. FFLV gives jobs to many locals in the schools, the kitchens, on the cultivation lands, sewing workshops etc.

4. Participation in political and community life. FFLV organizes social events, workshops and informative gatherings where the members of the local community can have their voices heard, and where they are given useful information and advice on how to make their life more productive. Political participation in India has been openly available for all citizens since independ- 
ence, but the inherent patriarchal social system has been an obstacle within the communities to have equally weighted participation and respect of opinion in the life of the community. Through the activities of FFLV this rigid social mesh is loosening up. FFLV organizes timely awareness drives, plays, and dances on social issues like child marriage, women abuse etc. to bring social awareness.

5. Environmental sustainability. FFLV encourages cooperation within the local community to make the environment sustainable. FFLV organizes creative activities to improve the living conditions of the community like litter, waste and garbage collection on public areas, tree planting and building water purifying and storing facilities. The first step to achieve environmental sustainability is to make the poverty stricken population aware that the public areas, the areas that are used by everyone is theirs and need to be taken care of by them. This is why the public educational programs and collectively executed environment cleaning and beautifying programs are the bases to achieve sustainability.

6. Human security and rights. The knowledge and skills earned by the locals in the schools and training centers run by FFLV will be an asset to them for the rest of their lives. Education, healthy life, decent standard of living, community awareness they all build the feeling of security.

7. Gender equality. FFLV operates schools for $1.300+$ girls in a community where according to the census statistic male literacy outnumbers the female by more than $13 \%$. Man and women should have the same rights to health, education, participation in community life, and enjoyment.
This comparative enquiry into the UN's human development dimensions and the activities of the FFLV shows a striking match in all the dimensions. This match stems not from the FFLV team's acquaintance with Sen's capability approach concepts $[56,57,58,59]$ or Mahbub ul Haq's HDI [60] but rather their desire to help the people of Vrindavan live with more choices and to provide them with the knowledge that there is more available in life. It seems that by being in close proximity to the local community and thereby compassionately observing the needs of the people, FFLV as a GI-SI activity, armed with the willpower to act, has come to the same understanding of human nature, albeit in a thoroughly practical way.

B). A quantitative analyses deals with gathered numbers for measuring, making a rank order or establishing categories. The development industry receives donations from states and international, national organizations and individuals to be spent on the projects. In the first decade of the $21^{\text {st }}$ century the OECD registered amount was 1.094.981 million USD. FFLV has collected in this same period of ten years a bit more than 4 million USD. The development industry's spending is supposed to manifest within the developing and underdeveloped countries. In numbers this means that the population of North America and EU has to be deducted from the global population. This gives a figure of 5.700 millions (five thousand and seven hundred million) in 2011. The population of the area where FFLV is active was 0,092 million (ninety-two thousand) in the same year. From these numbers we can calculate a rough per capita amount, Table 3.

\section{Comparing the development industry and FFLV in income and number of subjects}

Table 3

\begin{tabular}{|c|c|c|c|}
\hline & $\begin{array}{c}\text { Amount to be spent, } \\
\text { 2000-2010 } \\
\text { (USD millions) }\end{array}$ & $\begin{array}{c}\text { Population to be spent on } \\
\text { (in millions) }\end{array}$ & $\begin{array}{c}\text { Per capita } \\
\text { (USD) }\end{array}$ \\
\hline Development industry & 1.094 .981 & 5.700 & $\mathbf{1 9 2}$ \\
\hline FFLV & 4 & 0,092 & $\mathbf{4 7}$ \\
\hline
\end{tabular}

Source: own work, using data from various sources [61]

This "per capita" amount indicates, that the development industry had over four times the money to spend on every individual in the developing and underdeveloped world - which includes everyone in the Vrindavan area - than FFLV. Some critics might immediately claim that this is a vague, or going further, a distorted image. They are right, however the purpose of this quantitative comparison is not to search for the accountability of anyone, but to present an order of magnitude estimate in the difference between the financial possibilities of the two activities.

6. Conclusions. This research aims to make a contribution to two areas: broaden the GI-SI literature with a case study on a volunteer based organization with a dual objective of outward and inward purposes and to draw light on the importance of timeline examination in parallel to screenshoot like cross section analyses. Based on the results of the conducted research the following con- clusions can bemade:

i. At the start Food for Life Vrindavan was a fully volunteer grassroots innovation at start, then with a gradual increase in the number of people served and expansion in the fields of services it has become a social innovation, all along with dual purposes of outward and inward development.

ii. The results of the characteristics of its activities fit into the dimensions of human development established by the United Nations based on AmartyaSen's concept of the capability approach.

iii. The financial resources of FFLV are modest in comparison to the OECD financed development industry, with the former having access to merely a quarter of the latter's "per capita" funds available for the area of activity around Vrindavan.

The findings of this research may assist in the decision phase of grant awards. It is hoped that with the start 
of this new age of social media there is a chance for an ever increasing awareness concerning the inequality of life conditions around our globe which will definitely help adjust and subsequently refine well-working prac- tices within the development industry thus yielding optimal results. On the other hand this will in all likelihood give an impetus for many more FFLV-like programs to manifest.

1. The Capability Approach: An Interdisciplinary Introduction. Retrieved from http://citeseerx.ist.psu.edu/viewdoc/download?doi=10.1.1.196.1479\&rep=rep1\&type=pdf, pp. 6, 30.12.2017.

2. Woolcock, M., Narayan, D. (2000). Social Capital: Implications for Development Theory, Research, and Policy. The World Bank Research Observer, Volume 15, Issue 2, 1 August 2000, Pages 225-249. Retrieved from https://doi.org/10.1093/wbro/15.2.225.

3. What is Human Development? Retrieved from http://hdr.undp.org/en/file/what-human-development, 29.12.2017.

4. Smith, D.H. (1997). Grassroots Associations are Important: Some Theory and a Review of the Impact Literature. Nonprofit and Voluntary Sector Quarterly, 26(3), 269-306. doi:10.1177/0899764097263002.

5. Seyfang, G., Smith, A. (2007). Grassroots innovations for sustainable development: towards a new research and policy agenda. Environ. Polit, 16 (4), 584e603.

6. Pellicer-Sifres, V., et al. (2017). Grassroots Social Innovation for Human Development: An Analysis of Alternative Food Networks in the City of Valencia (Spain). Journal of Human Development and Capabilities, January 2017, doi: 10.1080/19452829.2016.1270916.

7. Hossain, M. (2016). Grassroots innovation: A systematic review of two decades of research. Journal of Cleaner Production. Retrieved from http://dx.doi.org/10.1016/j.jclepro.2016.07.140.

8. Alkire, S. (2002). Dimensions of Human Development. World Development, 30(2), 181-205. doi:10.1016/S0305750X(01)00109-7.

9. Structural Adjustment in Sub-Saharan Africa. $\quad$ Retrieved from http://documents.worldbank.org/curated/en/570911468768036645/pdf/multi-page.pdf, pp. 23, 29.12.2017.

10. Hickel, Jason (2014). Exposing the great 'poverty reduction' lie. Retrieved from www.aljazeera.com/ indepth/opinion/2014/08/exposing-great-poverty-reductio-201481211590729809.html, 29.12.2017.

11. Stiles, Daniel (1987). Classical versus grassroots development. Cultural Survival Quarterly Magazine. Retrieved from https://www.culturalsurvival.org/publications/cultural-survival-quarterly/classical-versus-grassrootsdevelopment, 30.12.2017.

12. Query Wizard for International Development Statistics. Retrieved from http://stats.oecd.org/qwids/\#? $\mathrm{x}=1 \& \mathrm{y}=6 \& \mathrm{f}=4: 1,2: 1,3: 51,5: 3,7: 1 \& \mathrm{q}=4: 1,2+2: 1+3: 51+5: 3+7: 1+1: 1,2+6: 1960,1961$, $1962,1963,1964,1965,1966,1967,1968,1969,1970,1971,1972,1973,1974,1975,1976,1977,1978,1979,1980,1981$, $1982,1983,1984,1985,1986,1987,1988,1989,1990,1991,1992,1993,1994,1995,1996,1997,1998,1999,2000,2001$, 2002,2003,2004,2005,2006,2007,2008,2009,2010,2011,2012,2013,2014,2015,2016, 30.12.2017.

13. Ferraro, V. (2008). Dependency Theory: An Introduction in The Development Economics Reader, ed. Giorgio Secondi (London: Routledge), 58-64. Retrieved from https://www.mtholyoke.edu/acad/intrel/depend.htm, 29.12.2017.

14. Post-Development Theory and the Discourse-Agency Conundrum. Retrieved from http://www.uio.no/studier/emner/sv/sai/SOSANT2530/v12/LIE_Post-Development\%20Theory\%20and\%20the\%20 Discourse-Agency\%20C.pdf, pp. 120, 29.12.2017.

15. Discourses of Development. Retrieved from https://www.bloomsbury.com/au/discourses-of-development9781859739457/, 29.12.2017.

16. United Nations Development Program, Human Development Report 1997, pp. 15. Retrieved from https://books.google.hu/books?id=0x7VOd6cRj4C\&pg=PA15\&redir_esc=y\#v=onepage\&q\&f=true, 29.12.2017.

17. The Human Development Index (HDI): “... is a statistical tool used to measure a country's overall achievement in its social and economic dimensions. The social and economic dimensions of a country are based on the health of people, their level of education attainment and their standard of living. ... Calculation of the index combines four major indicators: life expectancy, expected years of schooling, mean of years of schooling for education and Gross National Income per capita for standard of living." Retrieved from https://economictimes.indiatimes.com/definition/human-development-index, 29.12.2017.

18. Social and Economic Development - Volume VI. Retrieved from https://books.google.hu/books?id= gvDhDAAAQBAJ\&pg=PA104\&lpg=PA104\&dq=Social+and+Economic+Development+\%E2\%80\%93+Volume+ VI,\&source=bl\&ots=xNcj9qPpAT\&sig=aGme4M_ZmC7i5vPgA8nfdkHm86g\&hl=en\&sa=X\&ved=0ahUKEwjqjP Gsi9LYAhWpxaYKHfHtBSsQ6AEILjAB\#v=onepage\&q=Social\%20and\%20Economic\%20Development\%20\%E $2 \% 80 \% 93 \% 20$ Volume\%20VI\%2C\&f=false, pp. 104, 29.12.2017.

19. Streeten, P., et al. (1981). First Things First: Meeting Basic Human Needs in Developing Countries. Oxford University Press for the World Bank, London.

20. Hicks, J. (1983). «Revolutions» in economics, In: Classics and Moderns: Collected Essays on Economic Theory, volume III, Basil Blackwell, Oxford, 3-16, [Reprinted from S. J. Latsis (Ed.), Method and Appraisal in Economics, Cambridge University Press, Cambridge, 207-218].

21. Streeten, P. (1984). Basic needs: some unsettled questions. World Development, 12(9), 973-978.

22. Stewart, F. (1985). Basic Needs in Developing Countries. Johns Hopkins University Press, Baltimore, MD.

23. Doyal, L., Gough, I. (1991). A Theory of Human Need. MacMillan, Basingstoke. 
24. Gasper, D. (1996). Needs and basic needs: a clarification of meanings, levels and different streams of work. Institute of Social Studies Working Paper, No. 210, Institute of Social Studies, The Hague.

25. Stewart, F. (1996) Basicneeds, capabilities, and human development. In: A. Offer (Ed.). Pursuit of the quality of life. Oxford: Oxford University Press.

26. Beitz, C.R. (1986). Amartya Sen's resources, values and development. Economics and Philosophy, 2.

27. Nussbaum, M.C. (2000). Women and human development: The capabilities approach. Cambridge: Cambridge University Press.

28. Pospísilová, T. (2011). Grassroots Volunteering: Definitions, Concepts and Themes. Overview of literature. Retrieved from https://www.agora-ce.cz/archive_files/Grasroots_volunteering.pdf, 20.01.2018.

29. Anheier, H., List, R. (2005). Dictionary of Civil Society. London: Routledge.

30. Roberts, S. (2005). 'Grassroots initiatives in energy', paper presented at Grassroots Innovations for Sustainable Development Conference, UCL, London, 10 June 2005. Retrieved from http://www.uea.ac.uk/env/cserge/events/ 2005/ grassroots/index.htm, 21.01.2018.

31. Monaghan, A. (2009). Conceptual niche management of grassroots innovation for sustainability: the case of body disposal practices in the UK. Technol. Forecast. Soc. Change, 76(8), 1026e1043.

32. Reinsberger, K., et al. (2015). Photovoltaic diffusion from the bottom-up: analytical investigation of critical factors. Appl. Energy, 159, 178e187.

33. Phills, J.A.Jr., et al. (2008). Rediscovering Social Innovation. Stanford Social Innovation Review.

34. Mulgan, G., et al. (2007). Social Innovation: What it is, why it matters and how it can be accelerated. Skoll Centre for Social Entrepreneurship, Said Business School, University of Oxford.

35. Grimm, R., et al. (2013). Social Innovation, an Answer to Contemporary Societal Challenges? Locating the Concept in Theory and Practice. Innovation: The European Journal of Social Science Research, 26(4), 436-55. doi:10.1080/13511610.2013.848163.

36. Edwards-Schachter, M., et al. (2012). Fostering Quality of Life through Social Innovation: A Living Lab Methodology Study Case. Review of Policy Research, 29(6), 672-92.

37. Seven gems of Vrindavan. Retrieved from http://news.vrindavantoday.org/2016/06/seven-main-temples-ofvrindavan/ 30.12.2017.

38. "Radha-Krishna are the male and female aspects of God. Known as the Divine Couple, together they are the full manifestation of God.". Retrieved from http://www.krishna.com/god-male-female-or-both, 29.12.2017.

39. „Nagar Palika, also known as a Municipality, is an urban local body that administers to a city with a population of 10,000 to 30,000.” Retrieved from http://www.differencebetween.info/difference-between-nagar-nigam-and-nagarpalika, 29.12.2017.

40. Vrindavan Population Census 2011 - 2019. Retrieved from http://www.census2011.co.in/data/town/800795vrindavan-uttar-pradesh.html, 30.12.2017.

41. The History of Food for Life Vrindavan. Retrieved from http://fflvrindavan.com/en_sand/projects/, 30.12.2017.

42. Krishna-BalaramMandir: „,The Sri Sri Krishna Balaram Mandir, situated in the Raman Reti area of Vrindavan, is the grand temple of the devotees of the International Society for Krishna Consciousness...”. Retrieved from https://iskconvrindavan.com/about-us/, 29.12.2017.

43. Social Development. Retrieved from http://fflvrindavan.com/en_sand/projects/social-development/, 30.12.2017.

44. Niemets, L., Lohvynova, M., Kandyba, Y., Klyuchko, L., Kraynukov, O. (2018). Transformation of the agrarian sphere of Ukraine: approaches to study. Human Geography Journal, 24, 31-38.

45. Baranovskyi, M. (2017). Post-Soviet transformation of rural space in Ukraine: from polarization to decentralization. Human Geography Journal, 23(2), 23-29.

46. Save Our Girls. Retrieved from http://fflvrindavan.com/en_sand/girl-power/save-our-girls/, 30.12.2017.

47. Issues in Women"s Rights: A Practitioneres Resource Book. Retrieved from https://books.google.hu/books?id=QK-fAwAAQBAJ\&printsec=frontcover\&dq=isbn:8184249101\&hl=en\&sa=X\& ved=0ahUKEwiuwPDQh9LYAhWmIpoKHYe-C3AQ6AEIKDAA\#v=onepage\&q\&f=false, pp. 87, 30.12.2017.

48. Save Our Girls. Retrieved from http://fflvrindavan.com/en_sand/girl-power/save-our-girls/, 30.12.2017.

49. Fediy, O. (2014). The territorial organization of rural settling of Poltava region. Human Geography Journal, 16(1), 103-108.

50. For every 100 girls in rural India... Retrieved from http://www.fflv.org/blog/portfolio-item/social-development/, 30.12.2017.

51. Save Our Girls. Retrieved from http://fflvrindavan.com/en_sand/girl-power/save-our-girls/, 30.12.2017.

52. Motivation to prevent child marriage. Retrieved from https://www.icrw.org/news/motivation-to-prevent-childmarriage/, 30.12.2017.

53. Kononenko, I., Repin, A. (2016). The regularity of the country's GDP growth rate changes influence on the volume of gross fixed capital formation. Human Geography Journal, 21(2), 16-25.

54. Food for Life Vrindavan. Retrieved from http://us.fflv.org/fflv-global-offices/, 30.12.2017.

55. A Financial Account of Food for Life Vrindavan. Retrieved from http://fflvrindavan.com/en_sand/aboutus/finances/, 30.12.2017.

56. Sen, A.K. (1990). Development as capability expansion. In: K. Griffin, \& J. Knight (Eds.). Human development and the international development strategy for the 1990s. London: Macmillan. 
57. Sen, A.K. (1993). Capability and well-being. In: A. Sen, \& M. Nussbaum (Eds.). The quality of life. Oxford: Clarendon Press.

58. Sen, A.K. (1997). On economic inequality: with a substantial annex after a quarter century by J. Foster \& A. Sen (2nd ed.). Oxford: Clarenden Press.

59. Sen, A.K. (1999). Development as freedom. New York: Knopf Press.

60. Haq, Mahbub ul, et al. (1990). Human Development Report 1990, Published for the United Nations Development Programme (UNDP). Oxford: Oxford University Press.

61. Table 1, figure 6. Retrieved from https://esa.un.org/unpd/wpp/, 30.12.2017,

http://www.census2011.co.in/data/town/800795-vrindavan-uttar-pradesh.html, 30.12.2017.

Надійшла до редколегї̈ 30.09.2018 p.

\section{Про автора:}

Ласло Варга - аспірант (політологія) міждисциплінарної докторської школи, Печський університет, Угорщина, vargalaci108@gmail.com, https://orcid.org/0000-0003-0555-331X

\section{Об авторе:}

Ласло Варга - аспирант (политология) междисциплинарной докторской школы, Печский университет, Венгрия, vargalaci108@ gmail.com, https://orcid.org/0000-0003-0555-331X 